\title{
SYSTEMIC AND SYSTEMATIC STEPS OF LEADERSHIP ON TRANSFORMING SYMBOLIC INTO SUBSTANTIVE CHARACTERISTIC OF MADRASAH
}

\author{
Mohamad Iwan Fitriani \\ Institut Agama Islam Negeri (IAIN) Mataram \\ Jl. Gajah Mada Jempong Baru, Nusa Tenggara Barat, Indonesia, 83116 \\ Email: iwanfitriani@gmail.com
}

Received; February 2017; accepted June 2017; published June 2017

\begin{abstract}
This research studies headmaster's systemic and systematic steps on transforming symbolic into substantive characteristics of madrasah. The research was conducted at MA Nahdlatu Al-Wathan Putri Narmada, a female Islamic senior high school, in West Lombok, West Nusa Tenggara (NTB). This study used qualitative approach with a case study design. The results found that the observed symbolic characteristics are physical characteristics which distinguish madrasab from other educational institutions. The substantive characteristic is the characteristic of madrasab rooted in its origin, as a historical-genealogical continuance of pesantren. It also preserves the essential, perennial and contextually philosophical values of Islamic teachings, maintains the characteristics of Islam and follows the government policy at the same time because madrasah is a juridical sub-system of the national education with an Islamic integration. Additionally, the head of a madrasab is a translator of Islamic values in his leadership. These Islamic values should be the basis of systematic and systematic leadership.
\end{abstract}

Keywords: Characteristic, Madrasah, Headmaster, Systemic, Systematic.

\begin{abstract}
ABSTRAK
Artikel ini mengkaji tentang langkah-langkah sistemik dan sistematis kepala madrasah dalam tranformasi madrasah dari ciri simbolike ke subtantif. Penelitian dilakukan di MA Nabdlatul Wathan Putri Narmada, Lombok Barat, NTB. Hasil penelitian menemukan bahwa karakteristik simbolik adalah karakteristik berupa simbol-simbol fisik di madrasah yang membedakannya dengan lembaga pendidikan lainnya baik pendidikan umum di bawab kemendikbud ataupun lembaga pendidikan non-islam, sedangkan ciri substantif adalah ciri madrasah yang didasarkan pada originalitasnya yaitu: kelanjutan pendidikan pesantren secara historis-genealogis, melestarikan nilai-nilai ajaran Islam yang esensial, perennial dan kontekstual secara filosofis, menjaga karakteristik. islam sebagai lembaga pendidikan islam serta mengikuti kebijakan pemerintah karena madrasah adalah sub-sistem pendidikan nasional secara yuridis dan selalu menerapkan prinsip integrasi atau keseimbangan secara teologis dan kepala madrasah adalah penerjemah nilainilai islami dalam kepemimpinannya. Nilai-nilai islami tersebut harus dijadikan dasar dalam kepemimpinannya secara sistemik, dan sistematik.
\end{abstract}

Kata Kunci: Karakteristik, Madrasah, Kepala Madrasah, Sistemik, Sistematik.

\section{INTRODUCTION}

Lombok Island is not only popular with thousands of mosques but also its pesantren- Islamic boarding schools - where many private Islamic schools were established. Pesantren and madrasah in Lombok are inseparable from Nahdlatu al-Wathan, one of the biggest existing religious organizations. This organization has pesantren and madrasab in all districts or subdistricts of West Nusa Tenggara, from Mataram in the West and Bima in the East. It is founded by Tuan Guru Kyai Haji Muhamad Zainuddin Abdul Madjid, the charismatic and 
most famous Moslem Scholar (Tuan Guru) of Lombok. This study is further focused on one of the madrasabs under the religious organization Madrasah Aliyah Nahdlatul Wathan (MA NW) Nurul Haramain Putri Narmada.

Regarding the historical background, madrasah in Indonesia, particularly in Lombok, is different with madrasab in other Islamic countries. The existence of madrasab in Indonesia is inseparable from pesantren. Madrasah completes pesantren, the former Islamic institution. It rises and develops as a part of the Islamic education renewal (tajdid in this nation. Consequently, madrasah aims to continue the best practices of pesantren and to find its relevance with the dynamic social and cultural situation.

Etymologically, madrasah is an adverb of place (dharfu al-zamān) derives from darasayadrusu-darsan, diräsatan wa madrasatan which means generally a place to study (Al-Munawwir, $\mathrm{KBBI}$ ). However, terminologically, the meaning of madrasab in Indonesia has changed and developed from an Islamic institution which is excluded from the national educational system to a part of the national educational system. Now, madrasah is defined as a unit of the formal educational institution under the guidance of the religious department which holds general educational processes with Islamic characteristics.

Regarding the application of the Islamic education in madrasah, we will identify many problems. One of them is on its Islamic characteristics (al-khashaish al-islamiyyah). There are at least two opposite perspectives on studying Islamic characteristics of madrasab namely (1) studying Islamic characteristics of madrasah is useless since madrasah automatically has the characteristics which can be seen from its name, historical background and it is the Islamic education under ministry of religious department (Kemenag), not under national department of education and culture (Depdikbud), (2) studying Islamic characteristic of madrasab is useful and meaningful for many realities found in the social-empirical aspect in which madrasab often prefers its symbolic characteristic to symbolic one. This study chooses the second perspective for a reason that even though madrasah is under the ministry of religious department, but many madrasabs less actualise their Islamic characteristics, particularly the substantial ones (Muhaimin, 2009, pp. 175-179).

Deeply and comprehensively studying the Islamic characteristics of madrasah triggers a lot of problems. The problems are caused by a lack of understanding or misunderstanding of the Islamic characteristics, such as (1) those Islamic characteristics usually emerge and appear as an additional name only. For example, madrasab is an educational institution held by Moslem and called as the Islamic educational institution; (2) the Islamic characteristic of madrasab is often understood as a set of Islamic subjects or curriculum given by the Ministry of Religious Affairs such as Aqidah Akbläk, Qur'än Hadits, Fiqh, the history of Islamic civilization, and Arabic language. Consequently, madrasab is simply understood as an educational institution with additional religious subjects.

In line with the national education policy, each educational institution in Indonesia is obligated to hold a national examination (UN). A lot of madrasabs were trapped by pragmatic reasons through lessening times for religious subjects close to the national examination schedule because they are afraid of their students will get a failure in the examination. In this case, the religious subject is often regarded as a stepchild. Ideally, national examination policy does not mean it (Muchtar, personal communication, August 23, 2014).

Related to the above problems, Muhaimin (2014, pp. $75 \& 179)$ classified the problems of the Islamic education characteristic into symbolic and substantive. Symbolic characteristics mean that characteristics differ the Islamic education physically from others such as a nonMoslem educational institution or other educational institution under the Department of Education and Culture. The word symbol in this study also reflects any symbol seen or observed at madrasah. However, the symbolic characteristic is important, for it plays a big role 
to differ one institution, people or community with another. The problems are questionable when the symbol reduces and makes substantial characteristic vague and unclear or even loss of madrasah.

The substantive characteristic is defined as education which is (1) a tool to deepen the Islamic science and foster Islamic spirits and life practices; (2) to clarify and strengthen the existence of madrasab in order to meet even to surpass the national standard of education; and (3) able to respond future demands, to produce qualified graduates who are ready for the era of globalization and reform (Muhaimin, 2011, p.77). Thus, the Islamic characteristics of madrasah can be developed historically, philosophically, juridically or sociologically.

Actually many previous studies deal with leadership at madrasah. Some of them are as follows: (1) Mulyadi (2010) studied the leadership of madrasah headmasters in developing a quality culture. The research was conducted in the integrated madrasah of MAN 3 Malang, MAN Malang I, and MA Hidayatul Mubtadi'in Malang; (2) Julianto (2010) examined the spiritual leadership of pesantren students at pesantren Ulul Albab, Ulul Yaqin and Ulul Hikam; (3) Masaong (2009) studied the relationship of intellectual intelligence, emotional intelligence, spiritual intelligence, headmaster leadership style and school climate toward the school performance of secondary education in Gorontalo; (4) Fauzuddin (2011) analyzed the headmasters' informational leadership in two public schools and one outstanding public madrasah aliyah in Banda Aceh; (5) Firman (2012) studied headmasters' leadership at public boarding schools and multi-case studies at three public schools in the boarding school of Darul Ulum Rejoso Peterongan Jombang.

On the one hand, this research is directed to analyze a madrasab headmaster's leadership at a private Islamic school from the system perspective which categorizes the leadership into systemic and systematic leadership. The research relies on the concept that education is a system. So, to manage an educational institution interconnects and interrelates multiple elements and aspects to achieve teaching and learning goals. Moreover, education is not only composed of visible components but also invisible ones. So, all educational processes including the Islamic education - should involve the both components. Further, the research argues that the two components will be useless if the headmaster does not pay attention to the balance of the two components in his madrasah.

Therefore, the headmaster's leadership is important. He is the key agent of change. Bertocci (2009, p. 2), defines that leaders are agents of change, persons whose acts affect other people more than other people's do. The interesting statement is cited below:

"Leaders know where they are; where they are going or what has to be done; how they are going to get there (or how they are going to get the task done). They have a unique ability to get others to follow them. Importantly in this context, leaders can communicate their vision: this is where we are; this is where we want to go, and this is how we are going to get there. Leaders have the ability to present a clear path for followers to take and followers willingly follow them-whether the path leads to wartime combat, a business venture, or cleaning up one of the largest cities in the world." (Bertocci, 2008, p. xvi).

Based on the statement above, several important points related to the headmaster's roles need to answer. The points involve: (1) Where are they? They are at madrasab (which is different with the general school). They must realise that madrasah does not stand for a formal the Islamic education symbolically but also substantially. Madrasah came to continue and complete the traditional education system undertaken in pesantren; (2) What are they going to do? They are going to find, analyse or identify the Islamic education values from Islamic teaching main sources; (3) What does have to be done? They have to implement a suitable leadership type to find or identify the Islamic education values and drive those values to the whole the Islamic educational system. A different institution needs a different type or way of 
leading. They have a unique ability to get others to follow them; (4) How they are going to get the task done? Islamic values are not only found but also developed and used to build the Islamic educational system.

This study is oriented to discuss two points: (1) describe and analyse differences in the symbolic and substantive characteristics of madrasab; (2) describe and analyse headmaster's systemic and systematic steps on transforming the symbolic into substantive characteristics of MA Nahdlatu Al-Wathan Putri Narmada.

\section{METHOD}

This research was conducted at MA Nahdlatu Al-Wathan Putri Narmada, the female Islamic senior high school. There are several reasons - based on observation, documentation and interview with several teachers (Ikhtiyar, Riyanto, personal communication, May 4, 2015) about why this madrasab is chosen as the research site, namely (1) Madrasab Aliyah Nahdlatul Wathan Putri is one of the favourite private Islamic schools at West Lombok, NTB. The most interesting thing is when the majority of Islamic private schools in Lombok got difficulty in student recruitment, on the contrary, this madrasab was full of new student enrollments. It even developed and widened its area to another wider new place (Ikhtiyar, Riyanto, personal communication, August 23, 2015).

In the madrasah, the students are not only from West Lombok but also Centre Lombok, East Lombok, Sumbawa, East Nusa Tenggara (NTT), Java, Sumatra, Kalimantan and Sulawesi (Documentation, 2015); (2) The madrasah tries to integrate vertical, social and ecological religiosity of its students (Ikhtiyar, Riyanto, personal communication, August 23, 2015). So, it is no wonder if a lot of its graduates are recognised internationally. For example, Hasanain Djuaini, one of the graduates, got the Ramond Magsaysay international award from President of Philippine for the category of education, women empowerment, humanism and environment (Indri \& Ramzi, 2013, p. 102). He also obtains the Ma'arif award as a reformer in 2016. Additionally, Islamic culture comprised of Islamic values and activities. Therefore, the madrasah prioritises an enrichment of the students' achievement through knowledge, skill and behavior; (3) The national examinations result also shows the students and their parents' satisfactions. It means that the madrasah receives a good response from the stakeholders, which are called as customer satisfaction by Sallis (2002, pp. 14-15). According to Sallis, the quality or customer satisfaction is decided by outstanding teachers, high moral values, excellent examination results, parents' support, business and the local community, plentiful resources, applications of the latest technology, strong and purposeful leadership, pupils' and students' care and concern, a well-balanced and challenging curriculum.

\section{RESULTS AND DISCUSSION}

\section{A Brief Description of MA Nahdlatu Al-Wathan Putri Narmada}

MA Nahdlatu Al-Wathan Putri Narmada is one of private Islamic senior high school located at Jalan Hamzanwadi No. 5 Lembuak, Narmada, Lombok, NTB. It is under Nahdlatul Wathan Organization. Nahdlatul Wathan is the biggest Islamic organisation in Lombok and founded by Maulana Syeikh Tuan Guru Kyai Haji Muhamad Zainuddin Abdul Madjid in 1936. It is based on Islam Ablu al-Sunnah wa al-Jamäah ala Madzähi al-Syäfíiyyah. MA Nahdlatu Al-Wathan Putri Narmada becomes one of the favourite Islamic schools in West Lombok, NTB. When the majority of Islamic schools at Lombok are difficult to get new students, on the contrary, this Islamic school is full of new student enrollment. Thus, the students are socially plural. There are students from West Lombok, Central Lombok, East Lombok, Sumbawa, Dompu, Bima, East Nusa Tenggara, Bali, Java, Sumatra and Sulawesi. 


\section{Symbolic and Substantive Characteristic of MA NW Putri Narmada}

Precisely, the word symbolic characteristic in this study reflects several characteristics physically found at madrasab such as:

1. Women are compulsory to use a head cover. This obligation is not only given by madrasab but also other institutions. It means that the symbolic characteristic is not strictly owned by madrasah.

2. All of the students are Moslems (homogeny), whereas the other schools (non-madrasah) are heterogeneous.

3. The students greet and address others usually with as-salamu 'alaikum (peace be upon you) or ibtiram (respect to you), another school will vary such as as-salämu 'alaikum (peace be upon you), good morning, afternoon and etc.

4. All students study religion elaborately (Aqidah Akbläk, Qur'än Hadits, Fiqh and history of Islamic civilisation or even Arabic language), the students in the other schools study religion only in one subject, which is Islamic religious education.

5. The time allocation for the religion subjects in the madrasah is more than time to study religion in the other school.

6. All of leaders and teachers in the madrasah are Moslem, another school teachers will vary.

7. Madrasab is fully decorated with Islamic symbols such as a praying hall, Islamic proverb taken from Al-Qur'an and Hadiths. The other school may vary.

The mentioned symbolic characteristics are found in any madrasah, including at MA NW

Putri Narmada. Those characteristic are normal but the problem is the implementation influenced by the characteristics without paying more attention toward its substantial characteristics. What are substantial characteristics of MA NW Putri Narmada? To answer this question, it needs several perspectives.

1. Historical perspective

Madrasah puts itself as an agent for continuing and complementing pesantren. According to Azra (2010), the roles of pesantren are as follows: (a) to maintenance Islamic traditions, (b) to produce of ulama and, (c) to transfer Islamic knowledge. The opinion illustrates that what pesantren does should be followed and continued or even completed by madrasah. It also indicates that madrasah in Indonesia is historically different with madrasah in other (Islamic) countries. That is why developing the educational system of madrasab is inseparable from its origin. Madrasah comes from pesantren (a traditional Islamic boarding school). The origin, then, is used as a starting point to change or develop madrasah. The main characteristic of pesantren which should be continued by madrasah is its big attention toward the traditional Islamic knowledge. The term traditional here does not mean a conservative attitude but a big attention to past good habits. However, to conserve the tradition does not mean to forget the future, because Islam also instills its Moslem community to answer dynamic social changes all time and place. A popular slogan related to this matter is al-mubäfadhatu bi al-qadimi al-shälibi in one side and al-akbdzu or al-jjädu bi al-jadidi al-ashlabi in another side.

2. Philosophical perspective

The Islamic education may be defined as a transfer of values and a conservation of values. The best way to transfer value is education. The term of education in Islam is tarbiyah, it has similarities with the word rabb which means that the Islamic education must be based on divine values. Those values must be found, built up and developed to ensure the Islamic education excellence characteristic. In this case, Noeng Muhadjir (1987, p. 26) stated that one of education function is taking care of human and divine values.

3. Juridical perspective

Madrasah is not just an Islamic school but a unit of the formal educational institution under the Ministry of Religious Affairs to hold an educational process with Islamic 
characteristic. It should meet either the national standard or the Islamic education goals and objectives.

4. Religious perspective

Madrasab should be built upon and directed to integrate Moslem personalities. In contrast, the Islamic education is prohibited from bearing split personality. So, any educational process in the Islamic education must ensure balance several points such as (a) the balances between ta'lim and tarkiyah. In this case, ta'lim is understood as transfer of knowledge (cognitive aspect) and tarkiyah is understood as soul/heart purification, it's inspired by Qur'anic verseAlBaqarah: 151, (b) the balances between God's purpose in creating human being as abdullah and khalifatullah, it is inspired by Qur'anic verse Ali Imrān : 112, (c) the balance between theory and practice, it is inspired by Qur'anic verse as-Shāf: 3, (d) the balance between theory, practice and its manifestation, it is inspired by Qur'anic verse al-Ankabūt: 45, (e) the balance between belief (imān) and good deeds ('amalun shälibun). It is inspired by Qur'anic verse alRa'd: 29), ( $\mathrm{f}$ ) the balance between using rational and spiritual aspect (diiker and fikr), (g) the balance between the world and the here-after oriented, it is inspired by Qur'anic verse alQashas: 77, (h) the balance between struggling for anything physically and thinking deeply (jiha $\bar{a} d$ and $i j t i h \bar{a} d$ ), it is inspired by Qur'anic verse at-Taubah: 122, (i) the balance between physical and spiritual sense (Qur'anic verse, al-Nahl: 78) and (Qur'anic verse, al-Mukminūn: 78) (Fitriani, 2015a, pp. 171-177).

\section{Headmaster's Systematic Steps on Transforming Symbolic into Substantive Characteristics of Madrasah}

Systemic means the linkage between elements and systematic which is a logical sequence of used steps. Even, as asserted by Fullan (2004, p. 21), a leader must understand the interconnection of systems within the institution he leads. Stephen Rampur also stated that system approach can also be applied in the management. He states the system approach to management is a concept which views a company as an interconnected purposive system that consists of several business sections. The quote shows that the system would not only mean a way but also all components for supporting learning process (Rampur, 2016). Then, Abuddin Nata (2008, p. 141) mentioned that elements of the education system consist of vision, mission, goals, curriculum, teaching and learning, educators, students, management, infrastructure, finance, communication, evaluation, environment and communication networks. Inputs of education, from the system perspective, are three, namely: raw input, i.e. learners or students, instrumental input such as curriculum, educators, teachers, buildings, equipment activity as learning, methods, and environmental input including social and environmental nature such as family members, social, cultural, economic, local conditions, weather and other things which directly or indirectly affect the educational process.

Furthermore, when discussing the system, what should consider not only the concrete system (as the mentioned) but also the abstract. In the context of the Islamic education, this abstract system emphasises on the education component of the intangible aspect but strongly determines the continuity of other education concrete system components such as Islamic values that underlie all matters relating to the support of education in madrasabs. The abstract system will assist school development in knitting physical system of the Islamic education. Islamic values are an intangible component, it derives from the Islamic worldview, perceptions, expectation, assumptions and belief that is based on Islamic religious teachings.

The word systematically in the context of leadership has a relative meaning. Every leader has its own systematic ways of leading. In this study, systematics is a sequence of leadership steps derived from figures. The nature of transformational leadership as follows: building school vision, establishing school goals, providing intellectual stimulation, offering support, 
modeling best practices and important organisational values, demonstrating high-performance expectations, creating a productive school culture and developing structures to foster participation in school decisions (Bush, 2008, p. 13).

Gary Yukl (1994, pp. 311-315) also provides an overview of transformational leadership characteristics as follows: developing a clear and attractive vision, designing a strategy to achieve that vision, articulating and promoting the vision, acting with confidence and optimism, expressing a sense of followers belief, implementing previous success in small stages to build self-esteem, celebrating successes, using a dramatic and symbolic action to determine the major values, leading with examples, creating, modifying or eliminating cultural forms, and using the ceremonies of transition to help people go through changes.

To transform the symbolic into substantial characteristics of madrasah, Muhaimin (2011, pp. 76-77) said that, as a school typified by an Islamic institution (religion), madrasah develops continuously: (1) religious subjects elaborated from Islamic religious education such as Aqidah Akbläk, Qur'ān Hadìts, Fiqh, history of Islamic civilization and Arabic language; (2) religious climate at madrasab manifested in the Islamic atmosphere, the facilities, the implementation of Islamic methods and approaches in presenting all subjects, and the qualified and good behavior Moslem teachers. So, madrasah will be able to realise its ideal purposes.

Then, to overcome problems mentioned above, school leader plays a significant role to transform madrasah from symbolic to substantive characteristics. There is a transformational leadership model that consists of idealised influence, inspirational motivation, individualised consideration and intellectual stimulation. Idealised influence is defined as leader's behaviour and the follower's attributions about the leader. Inspirational motivation refers to the ways by which transformational leaders motivate and inspire those around them. The individualised consideration represents the leader's continuing effort to treat each individual as a special person and act as a mentor who attempts to develop their potential. Finally, intellectual stimulation represents the leader's effort to stimulate followers to be innovative and creative to define problems and approach them in new ways (Balyer, 2012, p. 581).

Bayler also stated that transformational leadership has three basic functions: (1) transformational leaders sincerely serve the needs of others, empower them and inspire followers to achieve great success; (2) they charismatically lead, set a vision, instill trust, confidence and pride in working with them; (3) with the intellectual stimulation, they offer followers of the same calibre as the leader (Castanheira \& Costa, 2011). In this model, the school becomes less bureaucratic and it functions as its own transforming agent. Instead of empowering selected individuals, the school becomes empowered as a collective unit (Balyer, 2012, p. 582). Leithwood (1994) as cited by Bush, conceptualises transformational leadership along eight dimensions: building school vision, establishing school goals, providing intellectual stimulation, offering individualised support, modelling best practices and important organisational values, demonstrating high-performance expectations, creating a productive school culture, developing structures to foster participation in school decisions (Bush, 2008, p. 13). The leadership theory of Yukl and Leithwood above will be combined, modified and presented in a figure that describes madrasab headmaster's systemic and systematic development steps.

Based on Figure 1, several efforts are required to apply by a headmaster or school leader. The efforts involve deciding Islamic values built upon the world-view, basic assumption, expectation and belief; building Islamic vision and mission; determining goals and objectives; communicating and articulating vision and mission, deciding strategy and model to achieve vision and mission. The strategy and model are directed to all components of learning teaching process (systemic approach): from a raw input, instrumental and environmental input, process, output and outcome. The abstract system (Islamic value) is unseen but it 
should be manifested in any other concrete system, for the Islamic education essentially is an actualization of Islamic values. Collaboration with another system out of school (supra system) and feedback (Fitriani, 2015b).

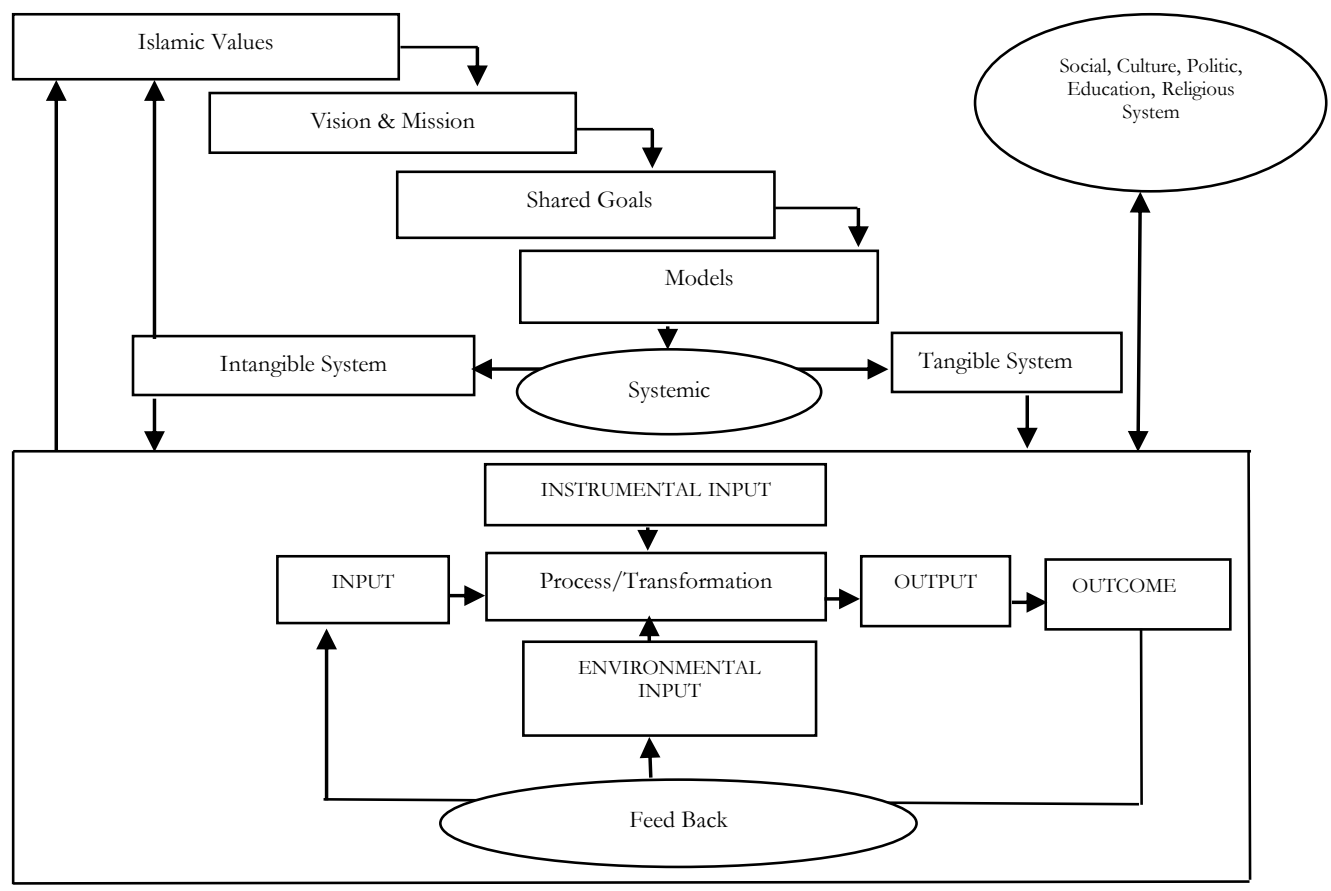

Figure 1. Systemic and Systematic Steps of Headmaster's Leadership.

Leadership model implemented by a headmaster in transforming symbolic characteristics into substantive ones can be seen through these chronological steps.

1. Determining the Islamic values.

Dealing with the value, Spranger (2006, p. 1) (as quoted by Bruno \& Eduardo) states that: values are defined as the constellation of likes, dislikes, viewpoints, shoulds, inner inclinations, rational and irrational judgments, prejudices, and association patterns that determine a person's view of the world. This was confirmed by David Grusenmeyer (2009). Even though we frequently talk about mission and vision first, the basic underlying foundation for both is our core values. Further, he also noted that the core values form the basis for our beliefs about life, ourselves and those around us, and the human potential of ourselves and others. Values and beliefs form our attitudes and guide our behavior (Grusenmeyer, 2009). The quote illustrates that the core values form the basis confidence of our lives and people around us. Debbarma also states that values are generally regarded as the moral standards of human behaviors in the society. It is a kind of quality of humans, which is applied to human activities. Values can be defined as the principles that guide people's lives and have varying significance. Values are the essence of our personality and affect us to make decisions, trust people, and arrange our time and energy in our social life. Values may be treated as keys to solving many world problems (April 2014, 182). Pesantren is popular with several Islamic traditions like conservation of religious values such as taräbum (respect each other), ta'äruf (knowing each other), ta'athuf (having a sense of empathy), ta'awnun (help each other), barakah (addition value of good deed) etc. For example, to get barakatu al-ílmi (addition value of knowledge and science), the students are not only taught to respect their teachers (al-asätidz) but also books they learn. From the book, they learn ways and methods of learning. Based on the interview result with ID, one of senior teacher at Nurul Haramain Putri Narmada (personal 
communication, August 28, 2015), those activities are called with birru al-ustädři (having good deed to teacher), birru al-ikhwäni (having good deed to friends), birru al-kutubi (having good deed to books which are studied), birru al-mushannifi (having good deed to the author of book by reading certain praying to him/her before studying the books). That Islamic tradition is now less found at student behavior. Most of the students feel innocent to put books they study in a back pocket of trousers.

Referring to Nurcholis Madjid (2001, pp. xv-xxi), in Islamic teaching, there are divine (rabbäniyyah) and human values (insäniyyah). Divine values such as iman, Islam, ibsan, taqwa, ikhlas, tawakkal, syukur and sabar. Human values such as shilaturrabim, ukbuwwah, al-musäwat, al'adl, busnu al-dhonni, tawädlu', wafä', insyiräh, 'iffah, ta'affuf, munfiqün. Next, Spranger (1990, p. 195) elaborated six values consisted of scientific value, economical values, art values, religious values, social and political values. What Nurcholis Madjid stated as the Islamic values (divine and human values) may be regarded as two points of the values stated by Spranger. Where the divine values stated by Nurcholis Madjid are the religious values in Spranger's perspective and human values by Nurcholis Madjid are the social values in Spranger's perspective. Leaders/headmasters should re-interpret and contextualise Islamic values from just narrow vertical and social values to wider vertical and social values as stated by two experts mentioned above. A leader is a translator (interpreter) of these values in all matters relating to educational development. Leaders role in this step is how to decide Islamic values based on Qur'an and Hadits and infuse them into the organization he/she leads. Islamic values driven by leaders to run an Islamic organization (such as madrasabs) are the combination of divine and human values in a wider meaning. Both of them are distinguishable but inseparable.

2. Developing visions, missions and goals based on the above values.

Vision is a picture or an ideal thing to be achieved by an institution. Furthermore, mission is operational of visions or a translation of vision statements into an organisation which focuses on its stakeholders' needs and on Islamic values. Thus, mission is an action to realise visions. Mission deals with aspects developed or implemented in realising visions. The next step is goals. Goals will determine the direction of any process that has been planned based on a job description of each component before.

The vision of MA NW Putri Narmada is to create good and right young Moslem generation who love beauty and live in welfare for themselves and other. According to ID, a teacher of MA NW Putri Narmada, this vision is inspired by the religious Islamic philosophy which concerns with ethic (good), right (logic) and beauty (aesthetic). Then, the missions of MA NW Putri Narmada are: (a) to develop the students' Islamic personality that the students obey religious teachings consistently (istiqamah), (b) to develop the students' Islamic personality that the students have a deep understanding of Islamic religion (al-mutafaqqibu fi aldin) and fight for Islamic religion (al-mujäbidu fi al-din) and (c) to develop the students' strong Islamic personality, good behaviour, willingness to fight, skill and capability to face the future (personal communication, August 28, 2015). Then, the vision and missions are required to actualise by the headmaster with his relevant directions to Islamic teachings as stated by the Qur'anic verse below.

"And we made from among them, leaders guiding with our command when they were patient and when they were certain of our signs" (As-Sajadah (32):24).

The headmaster further defines the developmental goals of madrassah. It is not only related to the objectives of the Islamic education but also the national education since the madrasab is a sub-system of national education. The idealised goals of MA NW Putri Narmada are as follows: 
1. To actualize madrasah as a religious based education.

Based on interview result with RY (personal communication, August 26, 2015), madrasah is one of the religious-based educations. Religious-based education means an education which is built by a certain religion, and madrasah is one of the educational institutions built by Moslem which differs from Pesantian (Hindu), school of theology (Christian), Pabaija and Samanera (Budha) and Shuyuan (Konghucu). As an Islamic institution, madrasab is directed to actualize its basis into learning teaching process. Islam perceives that education is a means of approaching God (taqarrub) by understanding his verbal and non-verbal verse.

Consequently, ID (personal communication, August 26, 2015) said, as a religious based education, the Islamic educational institution has mandatory to realise Islamic values, Islamic behavior and Islamic knowledge or science. The same statement comes from IKH who stated that religious based education must be followed with Islamic climate consists of Islamic values, activities and Islamic environment. All of those elements supports the optimisation of the Islamic educational system. AY (personal communication, August 26, 2015) also said that religious based education means an education built on high intention to actualize Islamic values through education. It plays a big role to differ an institution under Islamic religion with another.

2. To actualize madrasah as a continuer of former Islamic institution (pesantren).

As an agent for continuing or complementing pesantren, madrasab is demanded to actualize at least three roles of pesantren (Azra, 2010), which are as follows:

a) Transmission of Islamic knowledge; this role is applied by MA NW Putri Narmada through integrating curriculum of Nahdlatul Wathan (NW), it is a biggest social organisation at Lombok West Nusa Tenggara, curriculum of Modern pesantren Gontor Ponorogo, the curriculum of Religious Affair Ministry and Ministry of Education and Culture. That is why the madrasah is also accompanied with pesantren (Pesantren Nurul Haramain). The students study Islamic knowledge in the both madrasab and pesantren. In this context, it may be seen the difference between madrasab-pesantren and pesantrenmadrasah. The first shows that madrasah is firstly built and followed by pesantren and the second shows the contrary. At glance, there is no different between the both. The only difference will be found when they study and focus on their orientations. MA NW Putri Narmada is categorised as madrasab-pesantren, so it has a high orientation to be a modernised institution. It differs from pesantren-madrasab which has less modernization in its management. This fact brings into deeper next discussion about a classification of pesantren into salafy and kbalafy, in which modern and classic pesantren is not only seen as an integration of madrasab and pesantren or pesantren with madrasah but also in innovation aspect. Because along with runny and dynamic modernization era, modern pesantren cannot be simply seen as an institutional integration.

b) Maintenance of Islamic tradition.

c) Reproduction of ulama. To be an ulama, madrasah students are required to master not only religious subjects but also other sciences. In MA NW Putri Narmada, the students are prepared to have a deep understanding of instrumental knowledge and science (ilmu 'al-älat) consisting of Arabic and English language. One of the teachers said that it is difficult for the student in this modern era to be an ulama (in a wider meaning) without having any competence in foreign languages, since most of Islamic religious teachings are written or delivered by those languages (HS, personal communication, August 28, 2015). Thus, the students are motivated to master the instruments to be an ulama. The foreign language subjects are categorised as an instrumental science such as durüsu al-lughah (study about Arabic language), Nahwu, Sharf, Faräid, Fiqh, Ushülu al-fiqh, etc. 
3. To create a good organisation communication.

The headmaster communicates the vision and mission to all madrasah members through speech, writing or action. The communication is required to create a sense of belonging, responsibility and shared goals. It makes high consciousness in taking part or multiinvolvement. The vision, missions and objectives that have been communicated or disseminated would require a strategy to achieve them. It is the headmaster's key role to determine relevant strategies. In MA NW Putri Narmada, the best means for the vision and mission communication is student festivals involving all stakeholders-leaders, teacher, student, parent and experts. The delivery of vision, mission and goal through the student festivals is interesting for several reasons, as follows:

a) The students are managed to manage their selves (Ikhtiyar and Husnaen, personal communication, August 23, 2015).

b) The student's parent (wali santri) will be proud of their children who are able to perform their existence among the community (Riyanto, personal communication, August 28, 2015).

c) The other parents will be interested in entering their daughter to study at this pesantren (personal communication, August 23, 2015).

Tabel 1 is an example of interconnectedness among the Islamic values, vision, missions and goals in the development of the applied substantial characteristics of MA NW Nurul Haramain Putri.

Tabel 1. Interconnectedness Among the Islamic Values, Vision, Mission and Goals in the Development of the Applied Substantial Characteristic of MA NW Nurul Haramain Putri.

\begin{tabular}{|c|c|c|c|c|}
\hline No. & $\begin{array}{c}\text { Islamic Values } \\
\text { Balances }\end{array}$ & Vision & Mission & Goals \\
\hline 1 & $\begin{array}{l}\text { Jihäd } \\
\text { ijtibäd. }\end{array}$ & $\begin{array}{l}\text { Vision statement is } \\
\text { formulated and } \\
\text { directed to (example) } \\
\text { al-mutafaqqibu fi al-din } \\
\text { and al-mujähid fi al din. }\end{array}$ & $\begin{array}{l}\text { Mission statements } \\
\text { are directed to } \\
\text { realise/actualise the } \\
\text { students' intellectual } \\
\text { moral and physical } \\
\text { competences. }\end{array}$ & $\begin{array}{l}\text { Developing learning } \\
\text { teaching process that } \\
\text { supports the student's } \\
\text { ability in understanding and } \\
\text { implementing all good } \\
\text { knowledges that they } \\
\text { acquire. }\end{array}$ \\
\hline 2 & $\begin{array}{l}\text { Imän, Tlmu and } \\
\text { amal. }\end{array}$ & $\begin{array}{l}\text { Vision statement is } \\
\text { formulated and } \\
\text { directed to (example) } \\
\text { to be mu'min, muslim } \\
\text { and mubsin. }\end{array}$ & $\begin{array}{l}\text { Mission statements } \\
\text { are directed to } \\
\text { realise/actualise the } \\
\text { students cognitive, } \\
\text { affective and psycho- } \\
\text { motoric competences. }\end{array}$ & $\begin{array}{l}\text { Developing learning and } \\
\text { teaching process that } \\
\text { supports the student's } \\
\text { ability in understanding and } \\
\text { implementing all good } \\
\text { knowledge they acquired. }\end{array}$ \\
\hline 3 & Drikir and fikr. & $\begin{array}{l}\text { Vision statement is } \\
\text { formulated and } \\
\text { directedto (example) } \\
\text { students Intellectual } \\
\text { and spiritual. }\end{array}$ & $\begin{array}{l}\text { Mission statements } \\
\text { are directed to } \\
\text { Realize/actualize } \\
\text { students' competences } \\
\text { intellectually and } \\
\text { spiritually. }\end{array}$ & $\begin{array}{l}\text { Developing } \\
\text { teaching process thatning } \\
\text { supports the student's } \\
\text { intellectual and ritual } \\
\text { aspects. }\end{array}$ \\
\hline 4 & $\begin{array}{l}\text { Qauliyah and } \\
\text { kauniyah. }\end{array}$ & $\begin{array}{l}\text { Vision statement is } \\
\text { formulated and } \\
\text { directed to (example) } \\
\text { master religion, } \\
\text { sciences and } \\
\text { technology. }\end{array}$ & $\begin{array}{l}\text { Mission statements } \\
\text { are directed to } \\
\text { develop a balance of } \\
\text { textual and contextual } \\
\text { knowledge. }\end{array}$ & $\begin{array}{l}\text { Developing learning and } \\
\text { teaching process that } \\
\text { supports the student's } \\
\text { ability in understanding and } \\
\text { implementing science and } \\
\text { technology. }\end{array}$ \\
\hline 5 & $\begin{array}{l}\text { Balance } \\
\text { between } \\
\text { abdulläh and } \\
\text { kbalifatulläh. }\end{array}$ & $\begin{array}{l}\text { Vision statement is } \\
\text { formulated and } \\
\text { directed to (example) } \\
\text { have Good vertical } \\
\text { and } \\
\text { relationship. }\end{array}$ & $\begin{array}{lr}\text { Mission statements } \\
\text { are directed } & \text { to } \\
\text { develop a } & \text { good } \\
\text { vertical and } & \text { social } \\
\text { relationship. } & \end{array}$ & $\begin{array}{l}\text { Developing learning } \\
\text { teaching process that } \\
\text { supports the student's } \\
\text { ability to have a good social } \\
\text { and vertical relationship. }\end{array}$ \\
\hline
\end{tabular}


4. Determining strategy.

The strategy used was to prepare all components of education to support Islamic values as a base of madrasah composed of Islamic teacher, Islamic students, Islamic methods, an Islamic media, Islamic environment and goals. The strategy aims at two elements of educational resources: tangible and intangible resources. The intangible is described previously. The tangible is as follows.

a) Raw input: the students (with a variety of human nature (fitrah) to be developed such as taubid (the oneness of God), interests, aptitude, social and others.

In the Islamic education concept, one of education definitions is developing and taking care of students fitrah. Referring to Muhaimin and Mujib, there are many definitions of fitrab: (1) fitrah is holy or innocent (thuhr); (2) fitrah is Islam; (3) fitrah means confession to the oneness of God, (4) fitrah is pure, (5) fitrah is human condition tends to receive truths, (6) fitrah means basic human potentials, (7) fitrah means the origin design of human created by God, (8) fitrah means human nature and, (9) fitrah means ghorizah/instinct (Muhaimin \& Mujib, 1993, pp. 13-21). Headmasters should take care of potential of learners (human nature), it is not only developed but also cared. As a theo-anthropocentic education, headmaster of this madrasah concerns with the development of three integrated orientation of education namely; vertical, social and ecological religiosity. These orientations are distinguishable but inseparable in practice. According to ID, to actualize the three orientation, madrasah holds several programs classified into daily programs, weekly programs, monthly program, annually program and accidental program (ID, personal communication, August 26, 2015). Daily programs such as pray before and after studying, going to the mosque to pray together, memorising short verse of al-Qur'an and Hadits, discussion among student (mudzākarab) before taking rest at night, etc. The weekly program such as reading Hiqib (a collection of praying written by the founder of Nahdlatun Wathan Organization, TGKHM Zainuddin Abdul Madjid), reading Yäsin, etc. A monthly program such as reading hiæįb, training to preach with a foreign language. The annual program such as going to other places out of madrasab to widen students' outlook in religious and technological aspect or anything needed by students to survive under school programs. The accidental program is any activities needed to do such as visiting other sick friends, other institution, etc. The most important thing is program related to nature conservation nature in which students are involved in preparing seeds of trees, planting thousands of tree which are called with green haramain, etc.

All of those activities appear as an ordinary thing, but behind those programs, students are directed to habituate themselves with good things. Gradually, those will be a significant hidden curriculum for their next better lives. The purpose of those programs is a leader, teachers think students know without being taught since it has been living traditions among them. In this context, Joanna Konieczka stated that the rules that teachers think you know without being taught are called hidden curriculum. He also stated that hidden curriculum refers to unintended or implicit values cultivated in the practices exercised in the class room and educational institution (Joanna Konieczka December 2-6, 2016, p. 250)

b) Instrumental inputs such as teachers, media, methods, materials and evaluation.

However, everything was very much determined by the teacher's competencies in empowering the other instrumental input. In this case, teachers are required to meet three compulsory requirement: (1) the formal requirements (knowledge suitability with what is taught), (2) substantial requirements (religious aspects such as teacher's ability to read the Qur'an for every teacher at the school), and (3) complementary requirements (want to expand their experience). This relates to what Leithwood calls with intellectual stimulation. In this case, headmasters need to provide intellectual stimulation that leads to the madrasah human resources. Although they are teachers, they are still learning continuously. 
Instrumental inputs such as teachers, media, methods, materials and evaluation. In the book Diwannu as-Syäfíiy in the section dealing with tawädlu'ul 'ulamà stated that:

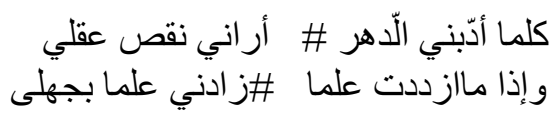

"When times educated me, it shows my lack of knowledge, when my knowledge increases, it increases my knowledge about my stupidity' (2005: 98).

Leaders should also show positive behaviours and values in the organisation. It is also called as an idealised influence in the transformational leadership. The idealised influence may also be seen as the behaviour of leaders who make followers admire, respect and at the same time believe them.

c) Environmental input

In this case, the headmaster has required his ability to establish a productive culture that supports the development of productive religious atmosphere in the madrasah. The religious atmosphere is built upon a combined system of madrasah and pesantren. The both system are filled with traditional Islamic values, activities and symbols. Environmental input is also supported by a structure that will realise all the stakeholders' participation in decision making. The structure is needed to describe the job description of each component in relation to what should be done, who will be responsible and to whom the responsibility is directed to. The structure determines who responsible for a specific job description.

d) Output and outcome.

To realise ideal outputs and outcomes, the headmaster are demanded to demonstrate high-performance expectations. The ideal outputs and outcomes are based on two main considerations: (1) regulation applied by the government, and (2) Islamic teachings interpreted from Qur'an and hadits. The output may be defined as students' performances, and achievement. It may be classified into academic and non-academic. Then, an outcome usually appears after an output is released. It deals with the students' social responsibility and acceptability in the society. Considering the government's policy in relation to the students' competence, it will be found four required output competences: spiritual competences, social competences, intellectual/knowledge and hard skills. The required outputs and outcomes from the integration of madrasah and school are seen in Table 2.

To run an educational system, it is not enough to see an institution from an internal system only. It need an external system to collaborate with, since any educational institution is an open system. Thus, to communicate or collaborate with other institutions is a must to do. A good educational institution will try to make material, intellectual and any possible partnership dealing with steps of developing quality of internal school systems. How to start this collaboration? It needs reciprocal values built by a creative headmaster. The reciprocal values mean that other institutions will respect the institution if they are respected first. They will help the institution, if they are helped. They will have sense of belonging if they are involved emotionally, intellectually (opinions) and etc. One way of building reciprocal values from the Islamic perspective is the contextualization of Hadits: "Whoever built a mosque, Allah would build for him a similar place in paradise."

The word mosque on the Hadits above, according to Muhaimin (2012), may be contextualized by school or madrasah. It is quite important to do since many Moslem people are highly motivative to take a part to build a mosque but less motivative to develop the quantity and quality of school or madrasah. The last steps are feedback, used to know if the applied process runs well or not. 
Tabel 2. The Relation of the Output Standards (in curriculum 2013) and the Desired Output by MA NW Nurul Haramain Putri.

\begin{tabular}{|c|c|}
\hline $\begin{array}{l}\text { Dimensions of } \\
\text { Competences }\end{array}$ & MA NW Nurul Haramain Putri \\
\hline Spiritual & $\begin{array}{l}\text { To be abdulläh (Mu'min, Muttaqin and } \\
\text { Mubsin): Qur'anic verse Ali Imran: 112, } \\
\text { Qur'anic verse Al Zariyat: } 51 \text { \& Hadits } \\
\text { about Imān, Islām and Ihsān. }\end{array}$ \\
\hline Social & $\begin{array}{l}\text { To be good khalifatulläh: (good social } \\
\text { relationship with others: mutakhalliq bi al- } \\
\text { akbläk al-karimah, ta'äwun, tasämuh, takäful } \\
\text { and tarähum. }\end{array}$ \\
\hline Knowledge & $\begin{array}{l}\text { Having deep knowledge and } \\
\text { comprehension on the Qur'anic verse and } \\
\text { God's creation (Qauliyah and Kauniyah with } \\
\text { Iqra' (reading, understanding, researching, } \\
\text { exploring, etc). }\end{array}$ \\
\hline Skill & $\begin{array}{l}\text { Having ability to actualise knowledge in } \\
\text { accordance with the Qur'anic verse and } \\
\text { God's creation (consistency between 'ilmu } \\
\text { \& 'amal, imān dan 'amal shäleh). It is also } \\
\text { said as: al-'alimu bi 'al-'amali wa al-'amilu bi } \\
\text { al-'ilmi (to know what he/she will do and } \\
\text { to do with suitable, relevant and adequate } \\
\text { knowledge). }\end{array}$ \\
\hline
\end{tabular}

\section{CONCLUSION}

As the Islamic education, madrasab is an undergoing unfinished agenda. There are several reasons. First, it is a natural thing for human being to have a better education, though they do not know what the best education actually means; Second, educational theories are always left behind since it is created based on dynamic social needs; Third, changes in the world-views also affect people's unsatisfaction toward education. In one time, people will be satisfied with an educational system for its relevance with his world-view and in another time. He/she may be affected by other world-views and consequently his/her world-views on education will change too. The statements above illustrate that there is no reason to stop looking for the best way to develop the education, including madrasah.

Symbolic characteristics mean a characteristic differentiate the Islamic education physically with other institutions such as educational institutions under the Department of Education and Culture. The Islamic characteristics of madrasab are not only understood as a physical aspect or the set of Islamic subjects or curriculum given by the Ministry of Religious Affairs such as Aqidah Abläk, Qur'an Hadits, Fiqh, the history of Islamic civilisation and the substantial characteristics. It is a characteristic built upon the historical, theological, philosophical and legal-juridical aspects. Those will be the comprehensive basic considerations on formulating its substantial characteristics. The headmaster's systemic steps on transforming the symbolic characteristics into the substantive characteristics of madrasah mean that the headmaster should use a systemic approach, which consist of the abstract and concrete system. The term systemic means that the headmaster ought to apply a logical-rational sequence of leadership steps which consists of values, visions, missions, goals, systemic strategies and models which cover input-process-output and outcome. An ideal the Islamic 
education development needs a systemic approach which differs from the partial or mechanistic approach. Education is a set of linked abstract and concrete elements or components which is required to pursuit ideal goals, based on the the Islamic education and the national educational policy of Indonesia.

\section{BIBLIOGRAPHY}

Azra, A. (2010). Islamic reforms in multicultural moslem Southeast Asia. In International Conference on Muslims in Multicultural Societies (pp. 14-16). Singapore.

Balyer, A. (2012). Transformational leadership behaviors of school headmasters: a qualitative research based on teachers' perceptions. Journal of Educational Sciences, 4(3).

Bertocci, D. I. (2009). Leadership and management. Lanham: University Press of America.

Bush, T. (2008). Leadership and management development. California: SAGE Publications.

Castanheira, P., \& Costa, J. A. (2011). In search of transformational leadership : a (Meta) analysis focused on the Portuguese reality. Procedia social and behavioural sciences, 15, 2012 2015.

Fauzuddin. (2011). Kepemimpinan transformasional kepala sekolah (Studi multikasus pada dua SMA Negeri dan satu MA Negeri berprestasi di kota BandaAaceh). Universitas Negeri malang. Retrieved from http://karyailmiah.um.ac.id/index.php/disertasi/article/view/11910

Firman. (2012). Kepemimpinan kepala sekolah pada sekolah negeri di pondok pesantern (Studi multikasus pada tiga sekolah negeri di Pondok Pesantren Darul Ulum Rejoso Peterongan Kabupaten Jombang). Universitas Negeri Malang. Retrieved from http:// karya-ilmiah.um.ac.id/index.php/disertasi/article/view/22358

Fitriani, M. I. (2015a). Manajemen pendidikan Islam, seri buku ajar IAIN Mataram. Mataram: Sanabil.

Fitriani, M. I. (2015b). Pola pengembangan program suasana religius melalui aktualisasi nilaiaktivitas dan simbol-simbol islami di madrasah. El-Hikmah, 9(1).

Grusenmeyer, D. (2009). Mission, vision, values and goal. Ithaca. Retrieved from https://ecommons.cornell.edu/handle/1813/36906

Julianto, M. E. (2010). Kepemimpinan spiritual pada pesantren mahasiswa (Studi multisitus pada pesantren mahasiswa Ulul Albab, Ulul Yaqin dan Ulul Hikam Malang). Universitas Negeri Malang. Retrieved from http://karyailmiah.um.ac.id/index.php/disertasi/article/view/11288

Masaong, A. K. (2009). Hubungan kecerdasan intelektual, kecerdasan emosional, kecerdasan spiritual, gaya kepemimpinan kepala sekolah dan iklim sekolah dengan kinerja sekolah pada pendidikan menengah di Kota Gorontalo. Universitas Negeri Malang. Retrieved from http://mulok.library.um.ac.id/index3.php/37110.html

Muhadjir, N. (1987). Ilmu pendidikan dan perubahan sosial: suatu teori pendidikan. Yogyakarta: Rake Sarasin.

Muhaimin. (2009). Rekonstruksi pendidikan Islam, dari paradigma pegembangan, manajemen kelembagaan, kurikulum bingga strategi pembelajaran. Jakarta: Rajawali Press.

Muhaimin. (2011). Pemikiran dan aktualisasi pengembangan pendidikan Islam,. Jakarta: Rajawali Press.

Muhaimin. (2014). W acana pengembangan pendidikan Islam. Yogyakarta: Pustaka Pelajar.

Muhaimin, \& Mujib, A. (1993). Pemikiran pendidikan Islam (Kajian pilosofik dan kerangka dasar operasionalnya). Bandung: Trigenda Karya.

Mulyadi. (2010). Kepemimpinan kepala madrasah dalam mengembangkan budaya mutu: studi multi kasus di madrasah terpadu MAN 3, MAN 1, dan MA Hidayatul Mubtadi'in Kota Malang. Jakarta: Badan Litbang dan Diklat, Kementerian Agama RI 
Nata, A. (2008). Manajemen pendidikan, mengatasi kelemahan sistem pendidikan Islam di Indonesia. Jakarta: Kencana.

Rampur, S. (2016). Understanding the systems approach to management is pretty easy. Retrieved March 23, 2017, from http://www.buzzle.com/articles/systems-approach-tomanagement.html

Sallis, E. (2002). Total quality management in education. Sterling: Stylus Publishing.

Yukl, G. A. (1994). Leadership in organizations. New Jersey: Prentice Hall. 